From the Gastrolentenolagiaal, Reselarch Unit, Princess Margaret Children Medical Research Foundation, Perth; Western Austmaliax.

\title{
Gastrointestinal Disease in Malnourished Children ${ }^{1,2}$
} $b y$

\section{MICHAEL GRACEY}

\section{Abstract}

In communities wehere malnutrition is common, gastrointestinal diseases are prominient and contribute largely to unfiavoumable monbridity and mortality statistics. Platterns of giastrountestinat dislease were studried in two such communities; Aboriginal children in Wiestern Austrialia and children admitted to the Dr. Cipto Maninurikusumo Gemenal Hospital, Jakiarta.

Two humidned and fifty one (251) young Aborigimes were studieid. Forty percent of them malnonirishad, $37 \%$ were anaemic alnd mone than 50\% had enteric pathogems in their stools. Sugair intollemamce was also common (25\%). Simition climical featumes ane seen in the children from Jakartia but mame slevere forms of malnutrition and grass vitamin dieficiency occurred more often.

Thirteien of the Aboriginal childmen died; at necropsy the most rein mankable finding was ficitty infiltnation of the liver which in some adses was extrieme. This, of course, is chamacteristic of protein-calorie molnutritiain and has bien well documiented in other studies. Other paithological findings includied sevene purulent infectians, septic, infiarcts, haemolysis, accanthooytosis, thrombocytoplenila and vascular catiastrophes.

1. This work was supported by a Grant from the Welcome Trust London.

2. Presented at the 3rd National Indonesian Paediatric Congress, Surabaya, July $106,1974$.

3. Adolph Basser Research Fellow of the Royal Australasian College of Phystcians. 


\section{Introduction}

Malnutrition is one of the main public health probilems facing mankind and is one of the main reasons for unsatisfactory morbidity and mortality in infants and children in pre-industrialized countries. Diarrhoeal disease is very common and, often, very serious in malnourished children, yet its pathogenesis ils poorby undersitiood.

This paper discusses the pathogenesis of diarrhoea in malnourished children. The information has been obtained from a review of the current literature and from the results of our collaborative research studies being done with members of the Department of Child Health, University of Indonesia. Reference will also be made to studies being done in this laboratory on malnourished Australlan aboriginal children.

The factors to be considered include:

(i) Intestinal infection and infestations

(iil) Abnormalities in small-intes tinal histology

(iii) Impaired digestive function

(iv) Poor absorptive function

(v) Overgrowth in the small intestine by organisms not generally considered 'enteropathogenic'

(vi) Possible abnormalitiles of immune function, and

(vii) Environmentall factors
Pathogenesiis of gastrointestinal disease in malnutrition

1. Intestinal Infections and Infestations

A high prevalence of infections and infestations of the gut is characteristic of malnutrition (Scrimshaw, et al., 1968). This is in contrast with well-nourished children in whom enteric pathogens are found in only 10 to $25 \%$ of patients. In malnourished Australian aboriginal children, for example, enteric pathogens occur in $50 \%$ and, many instances, multiple infections or infestations are common (Gracey, 1973) Often, infectilons with known enteropathogens can readily be implicated in the causation of d:arrhoea as, for example, in paticrits with gastrointestimal infection with pathogeric strains of Escherichia coil or with an infestation by the common intestinali parasite Giardia lamblia which has been shown to have deleterious effects on intestinal ultrastructure and function (Barbieri et all, 1970). Quite often, however, pathogenic micro-organisms will not be found in children with diarrhoeal illnesses despite repeated microbiological examinations of specimens of stooils.

It has recently been shown that viruses are also an important factor in young children with acute diarrhoea (Bishop et all., 1973) and perhaps are involved in the production 
FIG. 1 : Normaz steps in aigestion of laotose by laciase and absorpticin its competent monosaccharides by the small intestine.

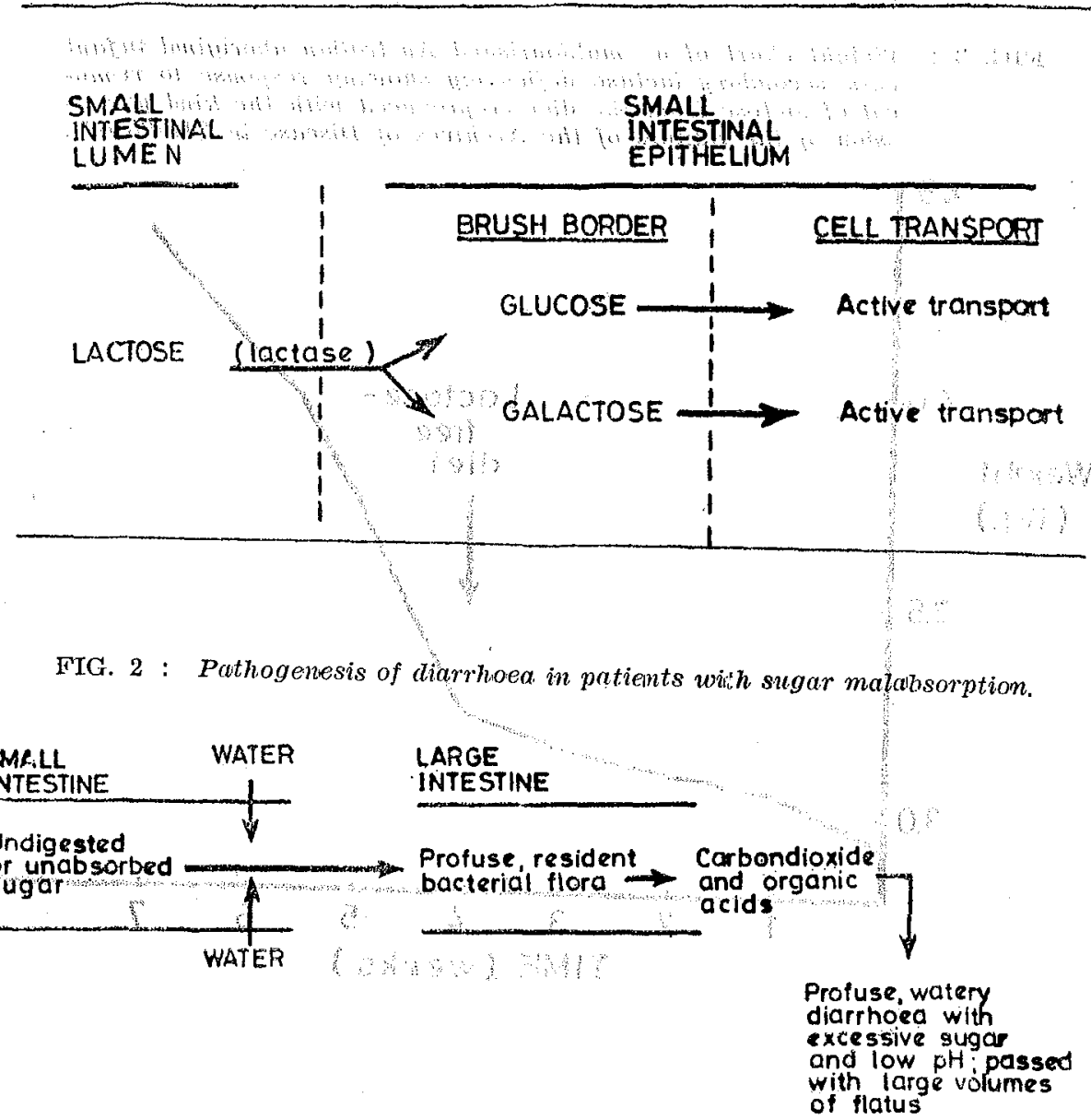


FIG. 3 : Weight chart of a malnourished Austmalian aboriginal inifant with secondary lactase deficiemcy showing response to removal of lactose from the diet (reproduced with the kimd permission of the Editors of the Archives of Disease in Childhood).

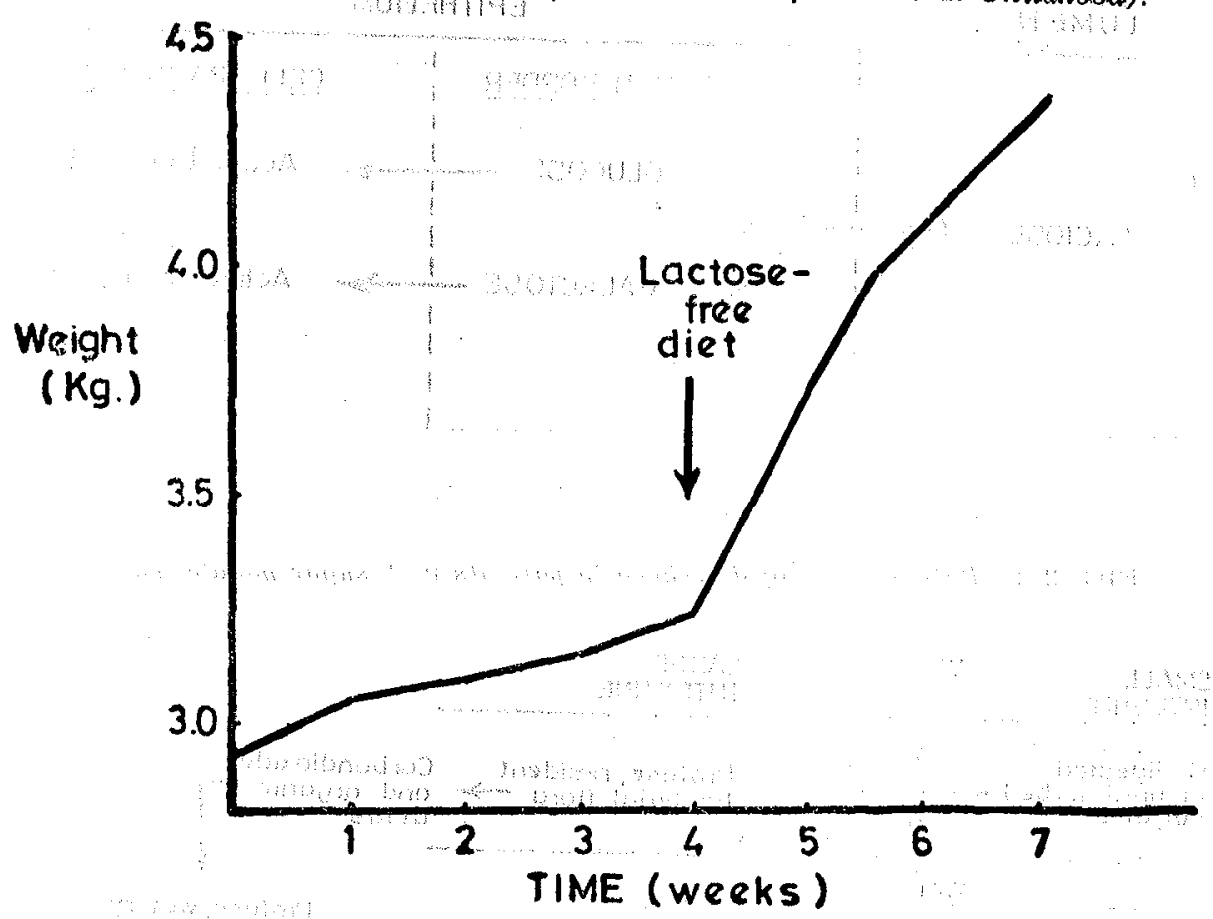


of gastrointestinial symptoms in malnourished children. Further investigations are needed to confirm this possilibilitity.

2. Histological changes in the small bowel epithellium.

Histological abnormalities in the epithelium of the upper' small bowel have been reported in malnourished children from many countries including Kenya (Burman, 1965), Uganda (Stanfileld et al., 1965) Chile (Brusner et al., 1966) and in Australian aboriginal chïldren (Harris et al., 1970; Walker-Smith and Reye, 1971). These changes appear to be common and may be very severe.

Recently, Shiner (1973) has shown extensive ultrastructural damage in small bowel biopsies from malnourished children. The pathogenesis of these changes is uncertain. There is no doubt, however, that they have important effects on gastroin. testinal' function as is outlined below.

3. Digestive function

It must be remembered that important digestive enzymes, such as disaccharidases, normally line the Iuminal surface of the smail intestinal epithellium (Miller and Crane, 1961) and are therefore very vulnerablle to damage in diseases with abnormalities of small intestinal histology. It is to be expected, then, that deficiencies of these enzymes occur in malnourished children in whom abnormal hlistology is common. Secondary disaccharidase deficiency has been reported from vanious centres (ie.g. Bowie elt all, 1965; Wharton et al., 1968; Walker and Harry, 1972). This is an important syndrome to recognize since these patients may have very severe, lifethreatening diarrhoea which will respond to removal of the offending sugar, usually lactose, from the diet.

It is essential that the pathogenesis of secondary sugar intolerance is thoroughly understood because successful treatment depends on a direct application of this knowledge. As can be seen in Figure 1, llactose is normally digested to its component monosaccharides (glucose and galactose) prior to absorption. In patients with a deficiency of the enzyme lactase, this does not occur and the undigested sugar atcracts large volumes of water into the lumen of the gut. When this load of sugar and fluid reaches the large intestine, the large numbers of micro-organisms normally present there produce acidic by-products and llarge volumes of carbon dioxide which is passed as flatus. (Fig. 2). Excessive amounts of sugar can be detected in the fluid part of the stool by the Clinitest method, a simple modification of the method used for detecting glycosuria (Kerry and Anderson, 1964). It must be stressed that this test

* Clinitest, Ames Company, U.S.A. 
must be done on the fluid part of the stool and that the specimen musit be fresh; if the specimen is allowed to stand around on a laboratory bench bacteria will rapildly break down any sugar present inito organic acids, such as llactic acid, and the test wijl therefore produce a 'false negative' result. Secondary lactase defiiciency wilf respond rapidly by cessation of diarrhoea and improved weight gain when a lactose-free diet is given (Fig. 3), Feeding formulae containing reduced amounts of lactose are now commercially available.**

Apart from lactase deficiency secondary to mucosal damage, it must be realised that lactase deficiency (possibly genetic in origiin) is common in certain ethnic groups including Indonesians (Suharjono at al., 1971). This is important in planning nutrittional rehabilitation programmes and foreign aid programmes which often include supplies of milk which may, in fact, be harmful to affected individuals.

\section{Absorptive function}

Apart from poor digestive function, malnutrition causes poor intestinal absorptilve function. The most important clnical result of this is Temporary Monosaccharide Malabsorption (Burke and Danks, 1966). This has been reported from several countries including Australia, (Wal- ker and Harry, 1972), Uganda (Wharton et al., 1968) and Latin America (Lifshitz et al., 1970). These children are oftenlyexitremely ill, with severe dehydration and acidosis and their mortality rate is very high. They can be recognized by showing excessive reducing substances in their stool's which continues when a lactose-free diet is given because they are unable to tolerate all sugars including glucose, galactose and fructose. They should be treated with a carbohydrate-free feeding formula and usually require intravenous fluids, It is likely that these children have malabsorption of other water-soluble nutrients such as amino acids which contributes to their diarrhoea and complicates their management.

5. Overgrowth of micro-organisms in the upper' gut

It seems likely that microbial overgrowth in the upper small bowel is a significant feature in malnourished infants and children with diarrhoeal illnesses. In malnourished Australlian aborigines we found (Gracey and Stone, 1972) a generalized and marked overgrowth by oral-itype and faecal-type micro-organisms in comparison with specimens of upper intestinal contents from well nourished

* e.g.Nutramigen, Mead Johnson; Galactomin, Trufood; Low Lactose Milk Food, Cow and Gate; Eiwlt Melk; Almiron-Nutricia, Holland.

* e.g.CF1, Nestlé, Australia. 
children. More recently we have found significant microbial contamination of aspirates from the upper gastrointestinal tract in 21 malnourished Indonesian patients (Gracey et al., 1973). A widde variety of orga. nisms were found including Staphylococci, E. colii, Pseudomonas sp., Sitreptococci, Anaerobic bacteria and Candida sp. (Gracey et al, in! press) The possible contribution of these microbilological abnormalities to the symptoms occurring in such patienits has not yet been elucidated although it is known that bacterial contamination of the upper small bowell results in various metabolic sequelae including malabsorption of fat, proteins and carbohydrates (Gracey, 1971).

Preliminary results from this laboratory (unpublished data) suggest that several organisms not generally considered to be 'enteropathogenic', including non-pathogenic varieties of E. coli, may cause impaired intestinal absorption of water-soluble nutrients. Our traditional ideas about enteropathogenicity may need considerable revision in the near future.

\section{Immunological function}

The guit is a major organ of immune defence and has a high rate of exposure Ito foreign antigens. It is important, therefore, to consider what circumstances allow gross overgrowth of this brgan to occur in malnourished children. Is it, for exampile, due to a break-down in the immune defence mechanisms allowing bacteria and yeasts to proliferate uncontrollled? Studies done in malnourished Australian aboriginal and Indonesian children show that these individuals do not have decreased levels of serum and intestinal immunoglobulins (Bell et al., 1973). In fact, their levels of immunoglobulins were significantly increased indicating that their immunoglobulins responses seem adequate. Cellular mediated immunity is known, however, to be impaired in malnutrition (Chandra, 1973) and it seems important that local intestinal cell-mediated immune responses should be investigated in infanits and children with malnutrition.

\section{Environmental factors}

In communities where malnutrition is endemic, living conditions are oyercrowded and unhygienic (Jelliffe, 1970). This is due to a combination of poverty, ignorance and unsa'sisfactory habuits in nutrition and hygiene. In a recent study, we found a high rate of isolation of signifficant numbers of faecal organisms not normally encountered in oro-pharyngeall secretions in malnourished children (Gracey et al., 1973). This emphasizes the importance of the faecal-oral route of transmission of infections and infestations in malnourished children living in unsatisfactory circumstances. It also re-emphasizes the importance of adequate 
educational and public health measures in preventive health programmes. Repeated hospital treatment is not onily expensive but it wilil be ineffective if children return to living in a grossly contaminated environment.

\section{The futture}

It should be alear from the foregoing discussion that the production of gastrointestinal disease in malnourished children is a very complex process which, as yeit, is not fully understood. One would seem justified in asking 'what is the point of undertaking sophisticated research investligations in children with malnutrition when the solution to their probilem would seem simple - more food?'. There are at least a couple of reasons why such studies are necessary. We have a grave responsibillity as professionals to indicate to those iesponsible for admimistering Government funds that malnutrition and intestinal disease are major problems in certain communities. Pcilitlicians and Government officials are not easily convinced by emotional pleas or poorly substantiated arguments.

They can, however be convinced by facts and figures. The financiall costs involved in current therapeutic health measures in hospultals would, in many instances, be more usefully employed in preventive programmes.

And, of course, we must convince these people that the future prosperity of any nation depends ultimately on the health of its children. Furthermore, results : of research studuies should be applied in clinical practice; one example is the useful place modified milk formulae, which were introduced only recently, now have in the management of children with sugar intolerance. Continued research into gestrointestmal disease in malnourished children will lead to betiter managemen of our patients and to a better understanding of gastroinitestinal disorders which will, eventually, benefit many children.

\section{REFERENCES}

1. BARBIERI, D,, DE BRITO, T., HOS. HIMO, S., NASCIMENTO F.OB., MARTINS CAMPOS, J.V, QUARTNTEL, G. and MARCONDES, E. : Giardiasis in childhood, absorption tests and biochemistry. " histochemistry, light and electron microscopy of jejunal mucosa. Arch. Dis Chlld. 45:466 (1970).

2. BELL, R.G., TURNER, K.J. and GRA CEY, M. : Serum and initestjnal immunoglobulins in malnourlshed children
Proc. aust. Soc. med. Res. $3: 140$ (1973).

3. BISHOP, R.F. DAVIDSON, G.P., HOLMES, I.H. and RUCK, B.J. : Virus particles in epithelial cells of duodenal mucasae from children with non-bacterial gastroenteritis. Lancet ii: 1281 (1973).

4. BOWIE, M.D., BRINKMAN, G.L and HANSEN, J.D, : Acquired disaccharide intolerance in malnutrition. $\mathrm{J}$. $\mathrm{Pe}$ diatr. $66: 1083$ (1965). 
5. BRUSNER, O., REID, A., MONCKEBERG, $\mathbf{F}$, MACCIONI, $A$ and CONTRERAS, I. : Jejunal biopsies in infant malnutrition: with special reference to mitotic index. Pediatrics 38: 605 (1966).

6. BURKE, V. and DANKS, D.M. : Mo nosaccharide malabsorption in young infants. Lancet i: 1177 (1966).

7. BURMAN, D.: The jejunal rnucosa in kwashiorkor. Arch. Dis Child. $40: 526$ (1965).

8. CHANDRA, R.K. : Immunocompetence in undernutrition. J. Pediatr. 81: 1194 (1972).

9. GRACEY, M. : Intestinal absorption in the "contaminated small-bowel syndrome", Gut 12 :403 (1971). Enteric disease in young Australian Aborigines. Aust. N.Z.J. Med. 3: 576 (1973).

10. GRACEY, M., SUHARJONO, SUNOTO and STONE, D.E. : Microbial contamination of the gut; Another feature of malnutrition. Am. J. clin. Nutr. 26: 1170 (1973).

11. GRACEY, M. and STONE, D.E. : Smallinitestinal microflora in Australian aboriginal children with chronic diarrhoea. Aust. N.Z.J. Med. 3 : 215

12. GRACEY, M., STONE, D.E, SUHARJONO and SUNOTO Oro-pharyngeal microflora in malnourished children. Aust. Prediatr. J. 9: 260 (1973). Isolation of Candida species from the gastrointestinal tract in malnourished chiddren. Am. J. clin. Nutr. (in press)

13. HARRIS, M.J., DUFFY, B.J. and BEVERIDGE, J.A Studies on the small bowel of a group of New South Wales Aboriginal Children. Med. J. Aust. $1: 356(1870)$.

14. JELLIFेEE, D:B Diarrhoeal disease of early childhood in Woodruff's Alimentary and Haematological A.spects of Tropical Disease pp. 145-181 (Edward Arnold, London 1970).

15. KERRY, K.R. and ANDERSON C.M.: A ward test for sugar in faeces. Lancet 1 : 981 (1964).
16. LIFSHITZ, F., COELLO RAMIREZ, P. and GUTIERRES-TOPETE, G. : Monosaccharide intolerance and hypoglycaemia in infant with diarrhea. I. Clinical course of 23 infants. J. Pediatr. 77 : 595 (1970).

17. MILIER, D. and CRANE, R.K. : The digestive function of the epithelium of the small intestine. II. Localization of disaccharide hydrolysis in the isolated brush border portion of intestinal epithelial cells. Biochem. biophys. Acta 52' 293 (1961).

18. SCRIMSAW, N.S., TAYLOR C.E. and GORDON J.E. : Interactions of $\mathrm{Nu}$ trition and Infection. WHO Monogr. Ser. No. 57, Geneva (1968).

19. SHINER, M. : A comparisin of ultrastructural appeorances fo Reticulin, Findothelium and Inflammatory cells of the jejunal mucosa in children with normal mucosae, untreated Coeliac Digease and Protein-Energy Malnutrition. in Proc. 6th annu. Meet. eur. Soc. paediatr Gastroenterol. Helisinki, August, 1973, p. 12 (1973).

20. STANFIELD, J.P., HUTT, M.S.R. and TUNNICLIFFE, $\mathrm{R}$. : Intestinal biopsy in kwashiorkor. Lancet ii : 519 (1965).

21. SUHARJONO, SUNOTO, ASWITHA BUDIARSO and SUTEJO: Lactose malabsorption in healthy Indanesian pre-school children. Paediatr. Indones. 11 : 251 (1971).

22. WALKER, A.C and HARRY, J.G. : A survey of diarrhoeal disease in malnourished Aboriginal children. Med. J. Aust. 1 : 904 (1972).

¿3. WALKER-SMITH, J.A. and REYE, R.D.K. : Small Intestinal Morphology in Aboriginal Children. Aust. N.Z.J. Med. 1 : 377 (1971).

24. WHARTON, B.A HOWELLS, G. and PHILLIPS, I. Diarrhoea in kwashior. kor. Br. med. J. 4 : 608 (1968). 